\title{
Reciprocal effect of parental lines on the physiological potential and seed composition of corn hybrid seeds
}

\author{
Juliana F. Santos ${ }^{1 \star}$, Lynnette M.A. Dirk ${ }^{2}$, A. Bruce Downie ${ }^{2}$, Mauricio F.G. Sanches ${ }^{1}$ and \\ Roberval D. Vieira ${ }^{1}$ \\ ${ }^{1}$ São Paulo State University (UNESP), School of Agricultural and Veterinarian Sciences, Department of Plant \\ Production, 14884-900, Jaboticabal, SP, Brazil; ${ }^{2}$ University of Kentucky, College of Agriculture, Food and \\ Environment, Department of Horticulture, Plant Science Building, 40546-0312, Lexington, KY, USA
}

(Received 10 October 2016; accepted after revision 24 February 2017; first published online 24 April 2017)

\begin{abstract}
Obtaining corn hybrid seeds (Zea mays L.) with high vigour depends on the parental lines and the direction of the cross, and this relates to seed desiccation tolerance and composition. This research studied reciprocal crosses between pairs of proprietary, elite parent lines ( $L 1$ and L5; L2 and L4) producing hybrid seeds with different qualities attempting to correlate vigour with seed composition, focusing on storage proteins, starch and soluble sugar amounts. Four corn hybrid seed lots produced from reciprocal crosses were compared (HS 15 with HS 51, and HS 24 with HS 42) by assessing germination, vigour, and seedling emergence in the field. Seed composition was assessed in mature, dehydrated seeds. Proteins were extracted, quantified, and analysed by electrophoresis and densitometry. Starch amounts were assessed using a kit and soluble sugars were determined using high performance liquid chromatography with pulsed electrochemical detection. The L1 and L2 lineages, used as female parents, provided seeds with lower vigour; however, the quantification of major protein bands, and sucrose, raffinose and stachyose were similar between seed lot pairs. While both total seed protein and starch varied between reciprocal hybrids for one of the two sets of crosses, the amounts of neither correlated with seed vigour. Interestingly, hybrids with low seed vigour (HS 15, HS 24) accumulated greater amounts of fructose relative to their reciprocal; correlation analysis confirmed these results. We demonstrate different effects on seed vigour dependent on the maternal parent in reciprocal crosses producing
\end{abstract}

*Correspondence

Email: julianafariaa@hotmail.com hybrid corn seeds. We also show that vigour is negatively correlated with seed reducing sugar contents.

Keywords: parental effects, raffinose, vigour, Zea mays (L.)

\section{Introduction}

Hybrid corn (Zea mays) seed, the progeny arising from crosses of specific endogamic lineages (true breeding inbred parents), provides the possibility of producing seeds with high physiological potential, defined in this manuscript as superior seed vigour. Superior seed vigour (characterized by an amalgam of axiomatic traits) from such hybrids is contingent on fortuitous combinations of parental morphological and chemical constitutions, resulting in vigorous hybrids and high productivity (Duvick, 2001), collectively referred to as heterosis. The continuing importance of hybrid seeds for helping to increase the production of the corn crop can be inferred from the United States Crop Production 2014 Summary (USDA, 2015). Despite decreases in the area harvested from 2013 to 2014 (35 to 33 million hectares), grain production increased approximately 3\% in the same period (USDA, 2015). To guarantee that hybrid seeds have high quality, it is essential to use compatible parental lineages. Even this is insufficient to guarantee high-quality corn seed, as several reports have demonstrated different phenotypes between reciprocal first generation $\left(\mathrm{F}_{1}\right)$ hybrids in corn (Egesel et al., 2003; Ordas et al., 2008; Lisec et al., 2011). These can sometimes be attributed to cytoplasmic effects, so-called maternal effects, from mitochondrial and chloroplast genomes (Rao and Fleming, 1978; Kollipara et al., 2002) inherited from the female, dosage effects in the endosperm, or imprinting (Guo et al., 2003), but variation in transcript 
amounts can also be attributed to the paternal parent (Swanson-Wagner et al., 2009).

It is important to point out that the nuclear genetic contribution of the parents to the various components of the maize seed are unequal. The pericarp (ovary wall) is of purely maternal genotype, the endosperm, including the aleurone layer, consists of two maternal and one paternal set of chromosomes (triploid), while the embryo is a diploid entity with equal parental genetic contributions. Thus the performance of hybrid seeds changes according to the selected genotypes, and differences between reciprocal crosses exist (Navratil and Burris, 1984; Roveri-José et al., 2004). This manifestation of phenotype may be attributable to seed chemical composition, especially regarding the quantity, identity and mobilization of storage proteins, lipids, starch and soluble sugars, as these can influence seed physiological potential (Footitt et al., 2002; McDonough et al., 2004; Vandecasteele et al., 2011), including quality (Wang and Frei, 2011).

The primary function of storage proteins is the supply of amino acids for the synthesis of enzymes and structural proteins during germination and subsequent early seedling growth (Bewley and Black, 1994; Herman and Larkins, 1999; Buckeridge et al., 2004). Amino acids produced from hydrolysis of the storage proteins can also be deaminated and, along with starch and lipid reserves, catabolized for energy production. In this way, greater storage reserve amounts in seeds can result in seedlings with greater vigour (Lowe and Ries, 1973; Bortolotto et al., 2008; Carvalho and Nakagawa, 2012). In addition, problems realizing full physiological potential in seeds can lead to poor desiccation tolerance (Hay and Probert, 1995; Faria et al., 2004). Desiccation tolerance is a characteristic acquired during orthodox seed development and maturation, and refers to the ability of seeds to endure dehydration, slow their metabolic activity and survive in the dehydrated state, increasing their longevity (Zhao et al., 2004; Li et al., 2011). This phenomenon ensures the transition of seeds from developmental to the germination stage (Kermode, 1997).

Many seeds with desiccation tolerance accumulate raffinose family oligosaccharides (RFOs) ( $\mathrm{Li}$ et al., 2011, Dinakar and Bartels, 2013) and have relatively few reducing monosaccharides (e.g. glucose and fructose) when dehydrated (Amuti and Pollard, 1977). The reduction in the monosaccharide content results in a decrease in substrates for respiration and can bring about metabolic quiescence, limiting the source of free radicals (Carvalho et al., 2008). Furthermore, monosaccharides contain reactive groups (aldehydes, ketones) and are therefore capable of attacking cellular constituents through Maillard reactions, thereby decreasing seed vigour (Murthy and Sun, 2000). Seeds and other desiccation-tolerant organisms usually convert these reducing sugars into non-reducing oligosaccharides (e.g. sucrose, RFOs) and polymers such as starch, thus avoiding such deleterious reactions (Koster and Leopold, 1988; Ingram and Bartels, 1996). In addition to being non-reducing sugars, RFOs are proposed to play important roles in seeds: functioning to protect biomembranes, proteins and intracellular structures during seed desiccation (Taji et al., 2002); acting as scavengers of reactive oxygen species (ROS; Nishizawa-Yokoi et al., 2008); and providing a source of rapidly metabolized carbohydrate for germination (Li et al., 2011). These soluble sugars may replace water on membranes and macromolecules by formation of anhydrous glass, vitrify the cytoplasm and fill and stabilize vacuoles (Dinakar and Bartels, 2013). In a previous study with sugars and tolerance to high temperature drying in corn seeds, it was verified that variation in the presence of sugars among hybrid seeds exists depending on the direction of the cross, but it was impossible to establish a relationship between tolerance to high temperature drying and sucrose, raffinose or a ratio of these sugars (Roveri-José et al., 2006).

Therefore, this research studied reciprocal crosses between pairs of proprietary, elite parent lines producing hybrid seeds with different qualities. It was our objective to correlate vigour, assessed using a battery of tests, with aspects of seed composition, focusing on proteins, starch and soluble sugar amounts present in the seeds.

\section{Materials and methods}

\section{Seed lot production, treatment and storage}

This research was conducted using four dent corn hybrid seed lots resulting from reciprocal crosses involving four endogamic lineages (L1 crossed with L5, and L2 crossed with L4) of propriety, elite lines, the hybrid progeny of which were designated as HS 15, HS 51, HS 24 and HS 42 (HS: hybrid seed; the first number corresponds to the maternal lineage and the second is the paternal lineage). The seeds were produced in Mocambinho, MG, Brazil (15 $5^{\circ} 10^{\prime \prime}$ S latitude, $44^{\circ} 0^{\prime} 58^{\prime \prime} \mathrm{W}$ longitude; altitude $462 \mathrm{~m}$ ); the sowing date was 15 April 2012, flowering time was 10 June 2012, and the ears were harvested on 6 August 2012 (average cycle for second-crop corn production in Brazil), when seeds reached physiological maturity (identified by the presence of the kernel black layer - approximately 30\% moisture content fresh weight). After the harvest, the ears were dried in a single-pass reversing dryer (35$40^{\circ} \mathrm{C}$ ) and seeds were manually extracted from the cobs (SWC in Table 1). The seed lots (defined as all fully developed, healthy kernels combined from each of the four reciprocal crosses named above) were identified, treated with fludioxonil and metalaxyl-M $(1.5 \mathrm{ml}$ $\mathrm{kg}^{-1}$ of seeds) and stored in a cold room $\left(10^{\circ} \mathrm{C}\right.$ and $50 \%$ air relative humidity) for the duration of the study. 
Table 1. Seed water content before (SWC) and after (SWCa) accelerated ageing, germination (GE), first count of germination $(\mathrm{FC})$, cold test (CT), accelerated ageing (AA), seedling emergence in the field (SE), and electrical conductivity (EC) tests of four corn hybrid seed lots originating from two reciprocal crosses after 9 months of storage

\begin{tabular}{|c|c|c|c|c|c|c|c|c|}
\hline Lots & SWC & SWCa & GE & FC & $\mathrm{CT}$ & $\mathrm{AA}$ & SE & $\mathrm{EC}$ \\
\hline & \multicolumn{7}{|c|}{$\%$} & $\mu S \mathrm{~m}^{-1} \mathrm{~g}^{-1}$ \\
\hline HS 15 & $12.6 \pm 0.11$ & $25.1 \pm 0.21$ & $90 \pm 2.22^{b}$ & $75 \pm 5.07^{b}$ & $61 \pm 2.52^{b}$ & $0 \pm 0.50^{\mathrm{b}}$ & $84 \pm 2.45^{b}$ & $19.4 \pm 0.79^{a}$ \\
\hline HS 51 & $12.3 \pm 0.16$ & $25.5 \pm 0.14$ & $100 \pm 0.50^{a}$ & $95 \pm 3.11^{\mathrm{a}}$ & $90 \pm 2.16^{\mathrm{a}}$ & $8 \pm 1.50^{\mathrm{a}}$ & $98 \pm 0.82^{\mathrm{a}}$ & $18.0 \pm 0.33^{\mathrm{a}}$ \\
\hline CV (\%) & - & - & 3.8 & 9.9 & 6.2 & 55.9 & 4.0 & 6.4 \\
\hline HS 24 & $12.0 \pm 0.03$ & $24.4 \pm 0.09$ & $99 \pm 0.48^{\mathrm{a}}$ & $86 \pm 3.74^{\mathrm{a}}$ & $100 \pm 0.50^{\mathrm{a}}$ & $75 \pm 3.32^{\mathrm{b}}$ & $100 \pm 0.50^{\mathrm{a}}$ & $11.2 \pm 0.11 b$ \\
\hline HS 42 & $12.3 \pm 0.13$ & $23.9 \pm 0.08$ & $100 \pm 0.00^{\mathrm{a}}$ & $96 \pm 1.7^{\mathrm{a}}$ & $99 \pm 0.58^{\mathrm{a}}$ & $95 \pm 1.00^{\mathrm{a}}$ & $96 \pm 1.26^{\mathrm{a}}$ & $7.8 \pm 0.20 \mathrm{a}$ \\
\hline CV (\%) & - & - & 0.82 & 6.4 & 1.1 & 5.8 & 2.0 & 3.4 \\
\hline
\end{tabular}

Means \pm standard error followed by the same letter in the column within each endogamic cross do not differ significantly at $5 \%$ level of probability according to Tukey's test. CV (\%), coefficient of variation.

Fungicides were added to the seeds to guard against fungal infection during storage.

\section{Seed lot tests}

After 9 months of storage, the lots were evaluated for seed water content, germination, vigour (first count of germination, cold test, accelerated ageing and electrical conductivity) and seedling emergence in field tests, according to the procedures detailed below.

Seed water content: two replications of 25 seeds were subjected to the oven-drying method, which uses 105 $\pm 3^{\circ} \mathrm{C}$ for $24 \mathrm{~h}$ (International Seed Testing Association, 2016). Results were expressed as percentage moisture content on a fresh weight basis.

Germination: four replications of 50 seeds per lot were distributed in rolls of germination paper (substrate) moistened with deionized water equivalent to 2.5 times the dry substrate mass, and kept in a germination chamber at $25^{\circ} \mathrm{C}$ in the constant light. Seedling evaluations were performed at 4 and 7 days after sowing; results were expressed as percentage of normal seedlings (International Seed Testing Association, 2016).

First count of germination: this was performed in conjunction with the germination test (above) recording the percentage of normal seedlings observed (defined according to International Seed Testing Association standards for this species; International Seed Testing Association, 2016) on the fourth day after sowing.

Cold test: four replications of 50 seeds per lot were distributed in rolls of germination paper moistened with deionized water equivalent to 2.5 times the dry substrate mass. After covering with a thin layer of soil, the rolls were placed inside a plastic box and kept in a cold room $\left(10^{\circ} \mathrm{C}\right)$ for 7 days in the dark. The rolls were subsequently transferred to a germination chamber at $25^{\circ} \mathrm{C}$ in the light, and seedling evaluations of normal seedlings (as a percentage of the total) were performed on the fourth day (International Seed Testing Association, 2016).

Accelerated aging: samples of 250 seeds per lot were spread in a single layer on stainless-steel screens and placed in plastic germination boxes $(11 \times 11 \times 3.5 \mathrm{~cm})$ containing $40 \mathrm{ml}$ of deionized water at the bottom. The boxes were maintained in a germination chamber at $45^{\circ} \mathrm{C}$ in the dark for $72 \mathrm{~h}$ (International Seed Testing Association, 2016). After the ageing period, two replications of 25 seeds were used to determine seed water content and four replications of 50 seeds were submitted to the germination test (see above), evaluated on the fourth day and expressed as a percentage of normal seedlings.

Electrical conductivity: after two days at ambient temperature prior to testing, four replications of 50 seeds per lot were individually weighed $(0.01 \mathrm{~g}$ precision) and soaked in $75 \mathrm{ml}$ deionized water at $25^{\circ} \mathrm{C}$ for $24 \mathrm{~h}$. Electrical conductivity was then measured on a MS Tecnopon mCA 150; results were expressed in $\mu S$ $\mathrm{cm}^{-1} \mathrm{~g}^{-1}$ (International Seed Testing Association, 2016).

Seedling emergence in the field: four replications of 50 seeds per lot were manually distributed in $2.5-\mathrm{m}$ rows at $3-\mathrm{cm}$ depth and $0.05-\mathrm{m}$ spacing between rows. Seedling emergence was recorded 14 days after sowing and the results were expressed as percentages (Nakagawa, 1999).

\section{Total protein extraction, quantification and electrophoresis}

To extract total protein, five mature dehydrated corn seeds from each lot were weighed, ground in an 
electric coffee grinder and then pulverized in liquid nitrogen using a pestle and mortar. Three buffers (A1, A2 and B), used sequentially, extracted albumins, globulins and prolamins/glutelins, respectively, according to their solubility in different solvents (Osborne, 1924). To the dry seed powder, $5 \mathrm{ml}$ of buffer A1 $\left[25 \mathrm{mmol} \mathrm{l}^{-1}\right.$ potassium phosphate, $\mathrm{pH} 7.0,10$ mmol $1^{-1}$ dithiothreitol [(2S,3S)-1,4-disulfanyl-2,3butanediol] (DTT) and $\left.0.1 \mathrm{~mol} \mathrm{l}^{-1} \mathrm{NaCl}\right]$ was added for homogenizing using a pestle and mortar. The slurry was transferred to a $15-\mathrm{ml}$ disposable tube for centrifugation $\left(15,000 \mathrm{~g}, 20 \mathrm{~min}\right.$ at $\left.4^{\circ} \mathrm{C}\right)$ and the resulting supernatant was recovered as the albumin fraction. To the pellet, $5 \mathrm{ml}$ of buffer A2 $\left(25 \mathrm{mmol}^{-1}\right.$ potassium phosphate, $\mathrm{pH} 7.0,10 \mathrm{mmol}^{-1}$ DTT and $1 \mathrm{~mol} \mathrm{l}^{-1}$ $\mathrm{NaCl}$ ) was added; and the suspension was vortexed prior to centrifugation (as above) to recover the supernatant representing the globulin fraction. The same procedure was conducted on the resulting pellet using $5 \mathrm{ml}$ of buffer B [62.5 mmol $\mathrm{l}^{-1}$ Tris- $\mathrm{HCl}, \mathrm{pH}$ $6.8,2 \%(\mathrm{w} / \mathrm{v})$ sodium dodecyl sulfate (SDS) and $10 \%$ $(\mathrm{v} / \mathrm{v})$ glycerol] to recover the prolamin/glutelin fractions (Krochko and Bewley, 1990).

After extraction, the albumin and globulin fractions from each lot were quantified against a bovine serum albumin standard (BSA; 0, 2, 4, 8, 12, 16 and $20 \mu \mathrm{g}$ $\mu \mathrm{l}^{-1}$ ) using a Coomassie Plus (Bradford) Assay Kit (Pierce Biotechnology, Rockford, IL, USA) according to the manufacturer's instructions. Three samples of each fraction from each lot were assayed and the absorbance $(595 \mathrm{~nm})$ measured on a Shimadzu UV2101 spectrophotometer (Shimadzu Scientific Instruments, Columbia, MD, USA). Due to the presence of sodium dodecyl sulfate (SDS), the prolamin/glutelin fractions were quantified by dilution with water before using the DC Protein Assay (Bio-Rad Laboratories Inc., Hercules, CA, USA) following the manufacturer's instructions with measurement at $750 \mathrm{~nm}$. Results were calculated as $\mathrm{mg} \mathrm{g}^{-1}$ of seeds.

Protein samples were separated on a variety of SDS polyacrylamide gels with $4-20 \%$ gradient Mini-PROTEAN $^{\circledR}$ TGX $^{\mathrm{TM}}$ precast gels (Bio-Rad Laboratories) giving the best resolution. For all gels, proteins were fractionated by electrophoresis conducted using the Mini-PROTEAN Tetra Cell system (Bio-Rad Laboratories) using SDS-PAGE running buffer (Laemmli, 1970). The protein samples $(20 \mu \mathrm{l})$, the molecular weight marker (low range SDS-PAGE standards; Bio-Rad Laboratories) and buffer (for empty lanes) were mixed with $10 \mu \mathrm{l}$ of $3 \mathrm{X}$ loading buffer $\left[187.5 \mathrm{mmol} \mathrm{l}^{-1}\right.$ Tris-HCl, $\mathrm{pH} 6.8,6 \%(\mathrm{w} / \mathrm{v})$ SDS, $15 \%(\mathrm{v} / \mathrm{v}) \beta$-mercaptoethanol, $30 \%(\mathrm{w} / \mathrm{v})$ sucrose and $0.006 \%(\mathrm{w} / \mathrm{v})$ bromophenol blue], boiled for $5 \mathrm{~min}$ and centrifuged at $16,000 \mathrm{~g}$ for $30 \mathrm{~s}$ prior to loading. After $1-2 \mathrm{~h}$ at a constant $80 \mathrm{~V}$, the gels were stained with Coomassie Blue and destained (Hames and Rickwood, 1998) until there was good contrast for the lowest molecular weight proteins without losing staining of the highest molecular weight proteins.

Scanned gel images from two separate gels where protein fractions from seeds for all four crosses (HS 15 , HS 51, HS 24, HS 42) were run in adjacent lanes through the same gel (e.g. Fig. 1) were uploaded into GelAnalyzer 2010 (GelAnalyzer.com, Dr Istvan Lazar). The various bands in each lane were identified and each band quantified on an arbitrary scale after background subtraction according to the manual instructions. These amounts were normalized for the total protein amount per lane among gels, specific band amounts adjusted based on this normalization, and average band quantities compared between reciprocal crosses using ANOVA (Statistical Analysis System, Inc., Cary, NC, USA).
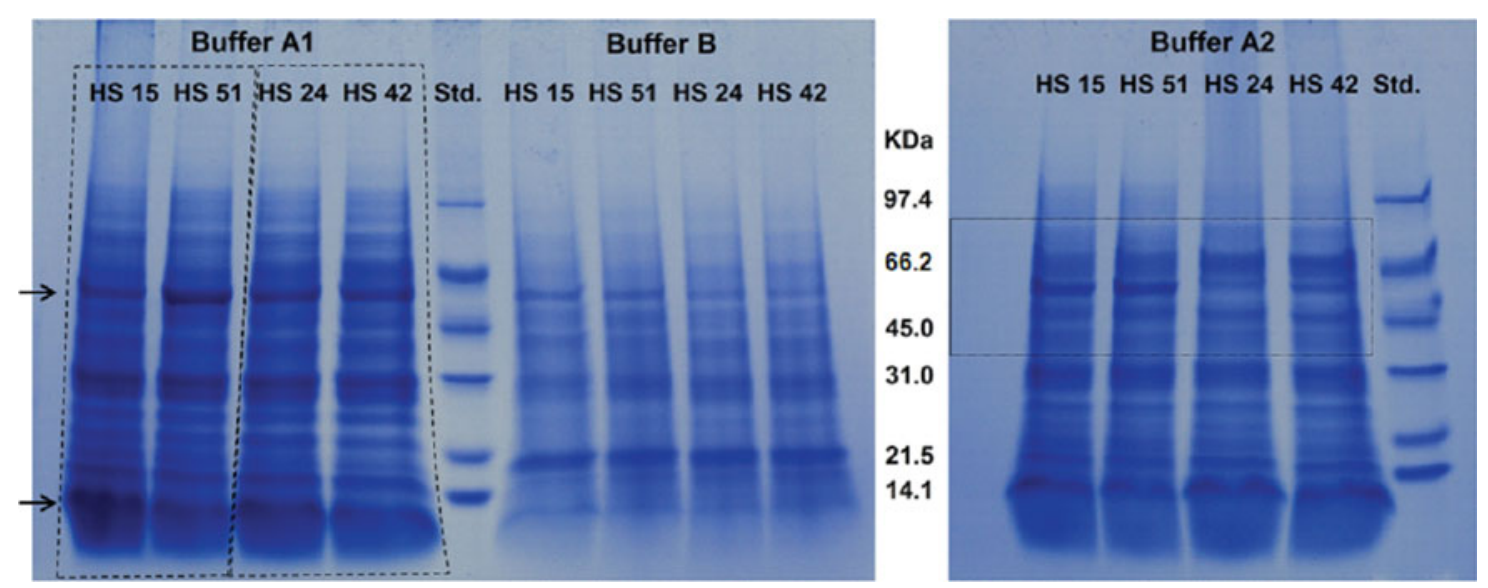

Figure 1. One-dimensional gel electrophoresis (SDS-PAGE) of albumins (Buffer A1), prolamins/glutelins (Buffer B) and globulins (Buffer A2) of four corn hybrid seed lots originating from two reciprocal crosses, after 9 months of storage. Std., standard molecular weight proteins; KDa, kilodaltons. 


\section{Starch extraction and quantification}

Three replications of five dehydrated corn seeds each per lot were weighed and, from them, the starch extracted and quantified using a kit (Total Starch Assay Kit, Megazyme, Inc., Wicklow, Ireland) according to the manufacturer's instructions.

\section{Sugar extraction, separation and quantification}

To extract sugars, three replications of five dehydrated corn seeds each per lot were weighed, ground in an electric coffee grinder and then pulverized in liquid nitrogen using a pestle and mortar. One aliquot of $1 \mathrm{ml} \mathrm{80 \%} \mathrm{(v/v)} \mathrm{ethanol} \mathrm{containing} 1 \mathrm{mmol} \mathrm{l}^{-1} 2$-deoxyglucose (2-DG), used as internal standard, was added to the seed powder, ground to produce a slurry, and transferred to a $15-\mathrm{ml}$ polypropylene tube on ice. The process was repeated four times with $1 \mathrm{ml}$ aliquots of $70 \%(\mathrm{v} / \mathrm{v})$ ethanol. Each time, after grinding the slurry, the $1 \mathrm{ml}$ was transferred to the same tube. This $5 \mathrm{ml}$ homogenate was centrifuged at $15,000 \mathrm{~g}$ for $20 \mathrm{~min}$ at $4^{\circ} \mathrm{C}$, the supernatant collected, diluted to $35 \mathrm{ml}$ with distilled, deionized water (precipitating the prolamins) and centrifuged again at $10,000 \mathrm{~g}$ for $10 \mathrm{~min}$ at $4^{\circ} \mathrm{C}$. The supernatant was recovered $(40 \mathrm{ml})$ and $10 \mathrm{ml}$ of each sample was added to $10 \mathrm{ml}$ of water in $50-\mathrm{ml}$ polypropylene tubes. After freezing at $-80^{\circ} \mathrm{C}$, the samples were lyophilized to dryness and reconstituted in $1 \mathrm{ml}$ distilled, deionized water by vortexing the samples (kept on ice) every hour for $8 \mathrm{~h}$. After transferring the sample to $1.5-\mathrm{ml}$ microtubes and centrifuging $(16,000$ $g$ for $30 \mathrm{~min}$ at $4^{\circ} \mathrm{C}$ ), the supernatants were collected and stored overnight at $-20^{\circ} \mathrm{C}$. Once filtered (CoStar Spin-X HPLC $0.45 \mu \mathrm{m}$ nylon filter, Corning Incorporated, Corning, NY, USA), the samples were diluted ten times with water prior to analysis or 100 times and re-analysed for better quantification of fructose and sucrose.

To identify and quantify the sugars, the diluted extracts were injected onto a Carbo-Pac PA1 guard column using a BioLC HPLC system with pulsed electrochemical detection (HPLC-PED) [ED50 detector and PeakNet software (version 6.0); Dionex Corporation, Palo Alto, CA, USA]. The separation via anion exchange used isocratic conditions of $19 \mathrm{mmol}$

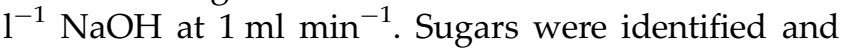
quantified by comparing their retention times and peak areas with that of known standards. Reintegration of the peak start- and stop-times, baseline identification, and areas under the curve were performed using Chromeleon software (version 6.8; Dionex Corporation). Estimates of sugar amounts per seed fresh weight were adjusted for losses during processing by comparing external standard 2-DG quantities with the recovery of 2-DG added during extraction (internal standard; Downie and Bewley, 2000; Nosarzewski et al., 2012).

\section{Treatment design and statistical analyses}

The treatments were distributed in a completely randomized design with four replications for germination, vigour and seedling emergence in the field tests, and three observations for the quantification of seed storage proteins, two gel observations for protein band intensities, and three replications for starch, and soluble sugars. A Pearson correlation analysis was performed between germination, vigour and seedling emergence in the field tests and the quantity of soluble sugars assessed by HPLC using three independent observations (replications) and two seed lots per reciprocal cross for a total of six points. The coefficient of variation in the tables is provided for the Pearson correlation analysis and is defined as the ratio of the standard deviation to the mean. This measurement indicates the amount of the variance of the female parent within each endogamic cross on each of the variables in the column, and expresses the precision and repeatability of the test. Mean values were compared with Tukey's test at a 5\% level of probability.

\section{Results and Discussion}

Although seed water content increased during accelerated ageing, it varied little between lots before or after accelerated ageing, and was within the recommended limit of two percentage points (Marcos-Filho, 2015a) (Table 1). This similarity between lots is important, as it relates to assessment standardization and result consistency (Rosseto et al., 2004).

All studied seed lots presented high germination percentages, above the minimum required for commercial sale, which is $80 \%$ (USDA, 2015) (Table 1). Nevertheless, despite similar unstressed germination percentages, several of the standardized vigour tests revealed underlying differences between hybrid seed lots dependent on the direction of the cross (Table 1). This distinction is possible because deterioration processes involve a continuum of events first manifest as a vigour loss and only subsequently as a reduction of germination percentage, emphasizing the importance of the use of vigour tests to precisely identify seed physiological potential (Marcos-Filho, 2015b).

The L1 lineage used as female parent (HS 15) had lower physiological potential than the reciprocal (HS 51) as evidenced by all the vigour tests, except electrical conductivity (Table 1). For the lots HS 24 and HS 42, both the accelerated ageing and electrical conductivity tests allowed their separation based on vigour, and in both tests HS 24 was less vigorous than 
HS 42 (Table 1). These two instances demonstrate that, in these reciprocal crosses, one line can produce seeds that are consistently and demonstrably inferior, viz. a reciprocal cross effect (Table 1). However, whether this substandard performance is attributable to the line used as the paternal parent or due to the maternal parent line is not evident from this study. Analyses from seeds of many additional reciprocal crosses with one or the other line serving in the same parental role recurrently would have to be assessed to attribute substandard performance to a particular line when used as a particular parent.

The same phenomenon has been observed in studies using popcorn and other corn hybrid seeds (Moterle et al., 2011; Cabral et al., 2013). In particular, the reciprocal cross effect in hybrid corn has been demonstrated in studies involving high drying temperatures (Roveri-José et al., 2004, 2006), physiological quality (Gomes et al., 2000) and in its influence on cold germination and desiccation tolerance (Kollipara et al., 2002). Findings reported here corroborate those in the literature which have steered long-standing production practices of choosing designated male and female parents during the installation of production fields. This practice maximizes the vigour of the hybrid progeny as it is influenced by cytoplasmic effects of maternal origin (Roveri-José et al., 2004) as well as gene dosage in the endosperm/aleurone layer (Chen, 2010), and the genetic identity of the pericarp which, as the ultimate tissue interface between the rhizosphere and the living seed tissues, may potentially influence vigour.

Another characteristic that can be determined genetically is the chemical composition of the seeds, such as storage protein, starch and soluble sugar contents (Bewley and Black, 1994; Song and Messing, 2003; Vandecasteele et al., 2011; Wu and Messing, 2014), and these can also influence seed vigour (Han et al., 2014). The mature maize endosperm is a major storage site for starch and protein, valuable storage reserves for the establishing seedling. Furthermore, only the aleurone layer of the maize endosperm is alive after maturation desiccation and functions primarily in reserve catabolism. Due to the different parental genetic contributions to the endosperm we anticipated possible gene dosage effects on vigour due to alterations in endosperm starch/protein content and/or the rapidity with which these reserves could be mobilized by the aleurone for use by the seedling. However, there was no correlation between starch content, protein content and seed vigour. The quantification of the seed storage protein fractions and the total extractable protein quantities did not differ between lots, except for the amounts of albumin in the crosses HS 24 and HS 42 (Table 2). Most enzymes are classified as albumins and are required for homeostasis, including enzymes involved in carbohydrate and proteinmetabolism (Tomić et al., 2015). Since the seeds were not submitted to stress, were not subjected to different storage conditions, and were not imbibed when sampled, the greater quantity of albumins in lot 24 can only indicate that this difference arose during seed development. Differences in seed soluble protein content have been determined to contribute to altered seed vigour previously (Lowe and Ries, 1973; Strelec et al., 2007; Borba et al., 2014) and seed storage reserve amounts, including protein, are known to be influenced by the maternal parent (Letchworth and Lambert, 1998).

The major storage proteins in corn seeds are the prolamins, also known as zeins, and they represent more than $50 \%$ of the total proteins in the endosperm (Reyes et al., 2011). A variety of genetic perturbations can reduce the synthesis of zeins and increase the synthesis of the other storage proteins (Wang and Larkins, 2001) and so we examined the quantities of specific proteins in one dimensional SDS-polyacrylamide gel electrophoretic profiles using densitometry. The electrophoretic profile of the storage protein fractions

Table 2. Quantification of seed storage protein fractions (albumins, globulins and prolamins/glutelins) and total extractable proteins of four corn hybrid seed lots originating from two reciprocal crosses after 9 months of storage

\begin{tabular}{|c|c|c|c|c|}
\hline Lots & Albumins & Globulins & Prolamins/glutelins & $\begin{array}{l}\text { Total extractable } \\
\text { proteins }\end{array}$ \\
\hline & \multicolumn{4}{|c|}{$\mathrm{mg} \mathrm{g}^{-1}$ of tissue fresh weight } \\
\hline HS 15 & $4.94 \pm 0.82(46.2)^{\mathrm{a}}$ & $2.70 \pm 0.35(25.3)^{\mathrm{a}}$ & $3.04 \pm 0.13(28.5)^{\mathrm{a}}$ & $10.68 \pm 0.50^{\mathrm{a}}$ \\
\hline HS 51 & $3.82 \pm 0.15(43.9)^{\mathrm{a}}$ & $1.78 \pm 0.37(20.5)^{\mathrm{a}}$ & $3.10 \pm 0.19(35.6)^{a}$ & $8.70 \pm 0.67^{\mathrm{a}}$ \\
\hline CV (\%) & 23.5 & 27.8 & 9.3 & 10.5 \\
\hline HS 42 & $3.62 \pm 0.19(41.8)^{\mathrm{b}}$ & $1.91 \pm 0.24(22.1)^{a}$ & $3.13 \pm 0.09(36.1)^{a}$ & $8.66 \pm 0.50^{\mathrm{a}}$ \\
\hline CV (\%) & 9.3 & 32.4 & 4.8 & 13.4 \\
\hline
\end{tabular}

Means \pm standard error followed by the same letter in the column within each endogamic cross do not differ significantly at $5 \%$ level of probability according to Tukey's test. Values within parentheses correspond to the percentage of the fraction in relation to the total proteins. CV $(\%)$, coefficient of variation. 
showed obvious differences between endogamic lineages (but not reciprocal $\mathrm{F}_{1}$ hybrids) in buffer $\mathrm{A} 2$, responsible for the extraction of globulins (Fig. 1). An examination of the protein bands, extracted in buffer A2, from just above 66.2 to just below $45 \mathrm{kDa}$ for HS 15/51 and HS 24/42 (dashed box in Fig. 1) revealed a qualitative disparity in proteins of possible relevance to the vigour differences observed when progeny 51, 15 (weaker) were compared with progeny 24,42 (stronger) (Fig. 1, Table 1). However, densitometry did not reveal remarkable differences in the electrophoretic profiles within any of the protein fractions between reciprocal crosses (Fig. 1).

The quantification of total protein did not allow differentiation between the seeds from reciprocal crosses (Table 2), nor have others observed striking differences in the general transcriptome profile (Stupar and Springer, 2006), or total protein amounts (Pollmer et al., 1979), between seeds of reciprocal crosses. However, in the current situation where qualitative differences between endogamic lineages were evident, it was surprising that no specific band intensity differences between reciprocal crosses were significant, especially given the differences in seed vigour (e.g. accelerated ageing results; Table 1). Because the lanes on SDS-polyacrylamide gels were loaded based on specific protein amounts $\left(20 \mu \mathrm{g}\right.$ lane $\left.{ }^{-1}\right)$ it was anticipated that there would be a significant difference in at least two protein species within a reciprocal cross for at least one of the extraction buffers. The corn proteome is known to undergo 'rebalancing' whereby a decline in abundance of a major protein species is compensated for by an increase in abundance of a, or a few, specific proteins (Schmidt et al. 2011; Herman, 2014; Wu and Messing, 2014), hence the anticipation of at

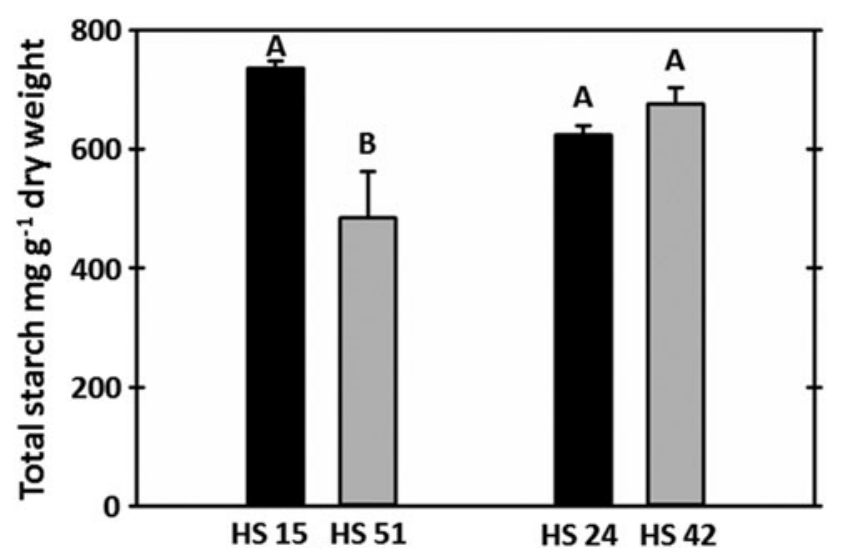

Figure 2. Total starch quantities ( $\mathrm{mg} \mathrm{g}^{-1}$ dry weight) of four corn hybrid seed lots originating from two reciprocal crosses, after 9 months of storage. Different upper case letters above the bars depict statistically significant differences among reciprocal hybrids within a cross using Tukey's experiment wise comparison at alpha $=0.05$. Bar height represents the mean \pm standard error.

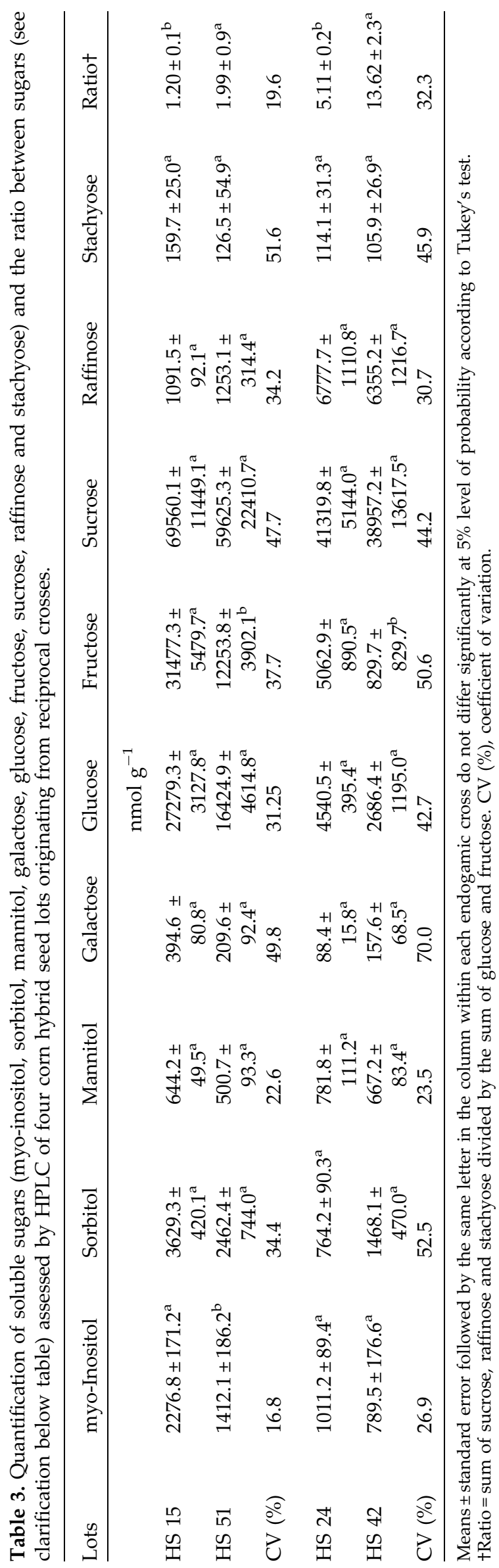


Table 4. Pearson correlation analysis between germination (GE), first count of germination (FC), accelerated ageing (AA), cold test (CT), electrical conductivity (EC), and seedling emergence in the field (SE) tests and the quantity of soluble sugars of two corn hybrid seed lots originating from reciprocal crosses (HS 15 and HS 51)

\begin{tabular}{llllllllrrr}
\hline & myo-Inositol & Sorbitol & Mannitol & Galactose & Glucose & Fructose & Sucrose & Raffinose & Stachyose & Ratiot \\
\hline GE & $-0.73^{*}$ & $-0.70^{\text {n.s. }}$ & $-0.58^{\text {n.s. }}$ & $-0.70^{\text {n.s. }}$ & $-0.72^{*}$ & $-0.70^{\text {n.s. }}$ & $-0.33^{\text {n.s. }}$ & $0.29^{\text {n.s. }}$ & $-0.30^{\text {n.s. }}$ & $0.64^{\text {n.s. }}$ \\
FC & $-0.70^{\text {n.s. }}$ & $-0.78^{*}$ & $-0.62^{\text {n.s. }}$ & $-0.72^{*}$ & $-0.74^{*}$ & $-0.64^{\text {n.s. }}$ & $-0.43^{\text {n.s. }}$ & $-0.25^{\text {n.s. }}$ & $-0.38^{\text {n.s. }}$ & $0.52^{\text {n.s. }}$ \\
$\mathrm{AA}$ & $-0.61^{\text {n.s. }}$ & $-0.27^{\text {n.s. }}$ & $-0.22^{\text {n.s. }}$ & $-0.34^{\text {n.s. }}$ & $-0.41^{\text {n.s. }}$ & $-0.62^{\text {n.s. }}$ & $0.14^{\text {n.s. }}$ & $0.27^{\text {n.s. }}$ & $0.09^{\text {n.s. }}$ & $0.90^{*}$ \\
$\mathrm{CT}$ & $-0.83^{*}$ & $-0.63^{\text {n.s. }}$ & $-0.58^{\text {n.s. }}$ & $-0.65^{\text {n.s. }}$ & $-0.72^{*}$ & $-0.81^{*}$ & $-0.26^{\text {n.s. }}$ & $0.15^{\text {n.s. }}$ & $-0.34^{\text {n.s. }}$ & $0.78^{*}$ \\
EC & $0.49^{\text {n.s. }}$ & $0.70^{\text {n.s. }}$ & $0.50^{\text {n.s. }}$ & $0.96^{\text {n.s. }}$ & $0.63^{\text {n.s. }}$ & $0.53^{\text {n.s. }}$ & $0.50^{\text {n.s. }}$ & $0.04^{\text {n.s. }}$ & $0.38^{\text {n.s. }}$ & $-0.25^{\text {n.s. }}$ \\
SE & $-0.84^{*}$ & $-0.64^{\text {n.s. }}$ & $-0.62^{\text {n.s. }}$ & $-0.74^{*}$ & $-0.77^{*}$ & $-0.88^{*}$ & $-0.32^{\text {n.s. }}$ & $0.14^{\text {n.s. }}$ & $-0.34^{\text {n.s. }}$ & $0.78^{*}$ \\
\hline
\end{tabular}

†Ratio $=$ sum of sucrose, raffinose and stachyose divided by the sum of glucose and fructose. Ratio: $(\Sigma($ Suc,Raf,Stc) $/ \Sigma(\mathrm{Glc}$, Frc $))$. n.s., nonsignificant at 5\%; 'significant at $5 \%$ level of probability according to Tukey's test.

least two differences when lanes were loaded on an equal protein basis. Nevertheless, no significant protein band intensity differences were evident between seeds of these reciprocal crosses, regardless of their differences in vigour.

Starch amounts between reciprocal crosses were not correlated with the vigour of the seed lot (Fig. 2). Thus starch quantities in the mature, dehydrated seed are apparently contributing little, if anything, to seed vigour performance in this study.

Considering the quantification of the soluble sugars in the seeds, lot HS 15 had greater concentrations of myo-inositol in relation to lot HS 51 (Table 3). According to Karner et al. (2004), studying barley and pea seeds, this sugar-like carbohydrate, associated with sucrose, positively affects the accumulation of RFOs. The non-reducing sugar sucrose, in conjunction with raffinose and stachyose, is thought to be important in the stabilization of the membrane system and in the protection of proteins in dehydrated seeds, positively correlated with desiccation tolerance and the maintenance of viability during storage (Singh et al., 2015). Therefore, a greater amount of sucrose was anticipated in lots with high vigour (Tables 1 and 3); and yet, no statistically significant differences between seeds from reciprocal crosses were identified for sucrose quantities, or for those of the RFOs, even when these seeds were of considerably different vigour (Tables 1 and 3). In fact, sucrose amounts were remarkably similar between lots from reciprocal crosses and the same was true for the RFO amounts. This is inconsistent with results obtained in other studies with bean (Bailly et al., 2001), corn (Chen and Burris, 1990; Roveri-José et al., 2006) and soybean seeds (Blackman et al., 1992), where lots with high physiological potential had greater concentrations of these sugars.

Seed lots with low vigour (HS 15 and HS 24) possessed high fructose amounts (Tables 1 and 3). There was a difference, especially evident between the HS 15 and HS 51 crosses, that fructose at least, was negatively correlated with vigour. Reducing sugar abundance was also found to be negatively correlated with seed vigour in suboptimal storage conditions in studies with mung bean (Murthy and Sun, 2000; Murthy et al., 2003). The negative relation between reducing sugar amounts and seed quality and longevity may be justified by the occurrence of Maillard reactions, which consist of a series of non-enzymatic reactions between reducing sugars and proteins or nucleic acids (Wettlaufer and Leopold, 1991; Lahuta et al., 2007). Maillard reactions may contribute to seed deterioration once they chemically alter proteins, thus

Table 5. Pearson correlation analysis between germination (GE), first count of germination (FC), accelerated ageing (AA), cold test (CT), electrical conductivity (EC), and seedling emergence in the field (SE) tests and the quantity of soluble sugars of two corn hybrid seed lots originated from reciprocal crosses (HS 24 and HS 42)

\begin{tabular}{|c|c|c|c|c|c|c|c|c|c|c|}
\hline & myo-Inositol & Sorbitol & Mannitol & Galactose & Glucose & Fructose & Sucrose & Raffinose & Stachyose & Ratiot \\
\hline GE & $-0.39^{\text {n.s. }}$ & $0.47^{\text {n.s. }}$ & $-0.38^{\text {n.s. }}$ & $0.33^{\text {n.s. }}$ & $-0.48^{\text {n.s. }}$ & $-0.44^{\text {n.s. }}$ & $-0.22^{\text {n.s. }}$ & $-0.13^{\text {n.s. }}$ & $-0.36^{\text {n.s. }}$ & $0.58^{\text {n.s. }}$ \\
\hline FC & $-0.38^{\text {n.s. }}$ & $0.21^{\text {n.s. }}$ & $-0.57^{\text {n.s. }}$ & $0.10^{\text {n.s. }}$ & $-0.37^{\text {n.s. }}$ & $-0.08^{\text {n.s. }}$ & $-0.30^{\text {n.s. }}$ & $-0.35^{\text {n.s. }}$ & $-0.61^{\text {n.s. }}$ & $0.20^{\text {n.s. }}$ \\
\hline $\mathrm{CT}$ & $0.35^{\text {n.s. }}$ & $0.03^{\text {n.s. }}$ & $0.16^{\text {n.s. }}$ & $0.12^{\text {n.s. }}$ & $0.38^{\text {n.s. }}$ & $0.32^{\text {n.s. }}$ & $0.41^{\text {n.s. }}$ & $0.28^{\text {n.s. }}$ & $0.28^{\text {n.s. }}$ & $-0.42^{\text {n.s. }}$ \\
\hline $\mathrm{EC}$ & $0.61^{\text {n.s. }}$ & $-0.58^{\text {n.s. }}$ & $0.49^{\text {n.s. }}$ & $-0.42^{\text {n.s. }}$ & $0.71^{\text {n.s. }}$ & $0.90^{*}$ & $0.20^{\text {n.s. }}$ & $0.25^{\text {n.s. }}$ & $0.22^{\text {n.s. }}$ & $-0.91^{*}$ \\
\hline SE & $0.34^{\text {n.s. }}$ & $-0.53^{\text {n.s. }}$ & $0.28^{\text {n.s. }}$ & $-0.40^{\text {n.s. }}$ & $0.41^{\text {n.s. }}$ & $0.79 *$ & $0.18^{\text {n.s. }}$ & $0.20^{\text {n.s. }}$ & $0.25^{\text {n.s. }}$ & $-0.86^{*}$ \\
\hline
\end{tabular}

†Ratio $=$ sum of sucrose, raffinose and stachyose divided by the sum of glucose and fructose. Ratio: $(\Sigma($ Suc,Raf,Stc)/ $\Sigma($ Glc, Frc)). n.s., nonsignificant at $5 \%$; ${ }^{*}$ significant at $5 \%$ level of probability according to Tukey's test. 
reducing the ability of the metabolic system to neutralize free radicals and to repair damage during germination (Wettlaufer and Leopold, 1991; Murthy and Sun, 2000).

Others have suggested that, rather than specific quantities of sucrose, RFOs and monosaccharides available in the dehydrated seed, it may be the relative amounts of these molecules that influences seed desiccation tolerance, longevity and vigour (Brenac et al., 1997; Vandercasteele et al. 2011). The ratio between the sum of oligosaccharides (sucrose and RFOs) and the sum of the monosaccharide reducing sugars (glucose and fructose) [ratio: ( $\Sigma($ Suc,Raf,Stc $) / \Sigma($ Glc, Frc $))$ ] revealed that the reducing sugar quantities were relatively greater in low vigour lots than in high vigour lots (Table 3). This is potentially one reason why the seed lots HS 15 and HS 24, even with high amounts of sucrose, presented lower physiological potential than seeds produced from the reciprocal cross (Table 1).

To investigate how soluble sugar amounts might influence parameters assessing seed vigour, a Pearson correlation analysis was made between the parameters measuring these two attributes (Tables 4 and 5). For lots HS 15 and HS 51, the content of glucose in the corn seeds showed a negative correlation with germination, first count of germination, cold test and seedling emergence in the field tests. Fructose content also correlated negatively with the cold test and seedling emergence in the field test. The ratio presented a positive correlation with the accelerated ageing, cold test and seedling emergence in the field tests (Table 4).

For lots HS 24 and HS 42, fructose content presented a negative correlation with the accelerated ageing test and a positive correlation with electrical conductivity and seedling emergence in the field tests. The opposite was observed for the ratio correlations (Table 5).

In conclusion, reciprocal effects of parental lines on seed composition and seed vigour were established for the seed lots tested in this project. Of the various compositional influences, the most consistent negative correlation with seed vigour between reciprocal crosses was with fructose amounts (a reducing sugar), and the ratio between oligosaccharide and monosaccharide amounts. Lower reducing sugar concentrations and greater amounts of non-reducing oligosaccharides are a hallmark of greater seed vigour (Koster and Leopold, 1988; Murthy and Sun, 2000) which was capable of differentiating between hybrid seed lots produced from reciprocal crosses of differing vigour in this study, potentially defining one determinant of heterosis. This relationship between reducing sugar presence and identity in maize seeds and seed vigour is one that is being investigated in attempts to better understand how different sugar species may differentially influence maize seed storability and seedling vigour through participation in Maillard reactions.

\section{Acknowledgements}

The authors wish to thank Dow AgroSciences for supplying the seed lots.

\section{Financial support}

The authors also thank FAPESP, São Paulo Research Foundation (processes 2011/23257-1 and 2014/011219) and CNPq, National Counsel of Technological and Scientific Development (process 305364/2013-8) for their scholarship and financial support throughout the project.

\section{Conflicts of interest}

None.

\section{References}

Amuti, K.S., and Pollard, C.J. (1977) Soluble carbohydrates of dry and developing seeds. Phytochemistry 16, 529-532.

Bailly, C., Audigier, C., Ladonne, F., Wagner, M.H., Coste, F., Corbineau, F. and Côme, D. (2001) Changes in oligosaccharide content and antioxidant enzyme activities in developing bean seeds as related to acquisition of drying tolerance and seed quality. Journal of Experimental Botany 52, 701-708.

Bewley, J.D. and Black, M. (1994) Seeds: Physiology of Development and Germination, 2nd edition. New York: Plenum Press.

Blackman, S.A., Obendorf, R.L. and Leopold, A.C. (1992) Maturation proteins and sugars in desiccation tolerance of developing soybean seeds. Plant Physiology 100, 225-230.

Borba, I.C.G., Bandeira, J.M., Marini, P., Martins, A.B.N. and Moraes, D.M. (2014) Antioxidative metabolism to separate seed lots with different homogeneity degrees [in Portuguese, with English abstract]. Revista Brasileira de Biociências 12, 20-26.

Bortolotto, R.P., Menezes, N.L., Garcia, D.C. and Mattioni, N.M. (2008) Protein content and physiological quality of rice seeds [in Portuguese, with English abstract]. Bragantia 6, 513-520.

Buckeridge, M.S., Santos, H.P., Tiné, M.A.S. and Aidar, M. P.M. 2004. Reserves mobilization [in Portuguese]. In Ferreira, A.G. and Borghetti, F. (eds), Germination: From the Basics to the Applied, pp. 163-185. Porto Alegre, Brazil: Artmed.

Brenac, P., Horbowicz, M., Downer, S.M., Dickerman, A. M., Smith, M.E. and Obendorf, R. (1997) Raffinose accumulation related to desiccation tolerance during maize (Zea mays L.) seed development and maturation. Journal of Plant Physiology 150, 481-488.

Cabral, P.D.S., Amaral-Júnior, A.T., Vieira, H.D., Santos, J. S., Freitas, I.L.J. and Pereira, M.G. (2013) Genetic effects on seed quality in diallel crosses of popcorn. Ciencia Agrotecnologia 37, 502-511. 
Carvalho, M.L.M., Nery, M.C., Oliveira, L.M., Hilhorst, H. W.M. and Guimarães, R.M. (2008) Morphophysiological development of Tabebuia serratifolia Vahl Nich. seeds. Sciencia Agricola 65, 643-651.

Carvalho, N.M. and Nakagawa, J. (2012) Seeds: Science, Technology and Production [in Portuguese], 5th edition. Jaboticabal, Brazil: FUNEP.

Chen, J.Z. (2010) Molecular mechanisms of polyploidy and hybrid vigor. Trends in Plant Science 15, 57-71.

Chen, Y. and Burris, J.S. (1990) Role of carbohydrates in desiccation tolerance and membrane behavior in maturing maize seed. Crop Science 30, 971-975.

Dinakar, C. and Bartels, D. (2013) Desiccation tolerance in resurrection plants: new insights from transcriptome, proteome, and metabolome analysis. Frontiers in Plant Science 4, 1-14.

Downie, B. and Bewley, J.D. (2000) Soluble sugar content of white spruce (Picea glauca) seeds during and after germination. Physiologia Plantarum 110, 1-12.

Duvick, D. (2001) Biotechnology in the 1930s: the development of hybrid maize. Nature Reviews 2, 69-74.

Egesel, C.O., Wong, J.C., Lambert, R.J. and Rocheford, T.R. (2003) Gene dosage effects on carotenoid concentration in maize grain. Maydica 48, 183-190.

Faria, M.A.V.R., Von-Pinho, R.G., Von-Pinho, E.V.R., Guimarães, R.M. and Freitas, F.E.O. (2004) Germinability and desiccation tolerance in corn seeds harvested at different maturation stages [in Portuguese, with English abstract]. Revista Brasileira de Milho e Sorgo 3, 276-289.

Footitt, S., Slocombe, S.P., Larner, V., Kurup, S., Wu, Y., Larson, T., Graham, I., Baker, A. and Holdsworth, M. (2002) Control of germination and lipid mobilization by COMATOSE, the Arabidopsis homologue of human ALDP. EMBO Journal 21, 2912-2922.

Gomes, M.S., Von-Pinho, E.V.R., Von-Pinho, R.G. and Vieira, M.G.G.C. (2000) Heterosis effect on the physiological quality of corn seeds [in Portuguese, with English abstract]. Revista Brasileira de Sementes 22, 7-17.

Guo, M., Rupe, M.A., Danilevskaya, O.N., Yang, X. and Hu, Z. (2003) Genome-wide mRNA profiling reveals heterochronic allelic variation and a new imprinted gene in hybrid maize endosperm. Plant Journal 36, 30-44.

Hames, B.D. and Rickwood, D. (1998) Gel Electrophoresis of Proteins: A Practical Approach, 2nd edition. Oxford, UK: Oxford University Press.

Han, Z., Ku, L., Zhang, Z., Zhang, J., Guo, S., Liu, H., Zhao, R., Ren, Z., Zhang, L., Su, H., Dong, L. and Chen, Y. (2014) QTLs for seed vigor-related traits identified in maize seeds germinated under artificial aging conditions. PLOS ONE 9, e92535.

Hay, F.R. and Probert, R.J. (1995) Seed maturity and the effects of different drying conditions on desiccation tolerance and seed longevity in Foxglove (Digitalis purpurea L.). Annals of Botany 76, 639-647.

Herman, E.M. (2014) Soybean seed proteome rebalancing. Frontiers in Plant Science 5, 437. doi: 10.3389/fpls.2014.00437.

Herman, E.M. and Larkins, B.A. (1999) Protein storage bodies and vacuoles. Plant Cell 11, 601-613.

Ingram, J. and Bartels, D. (1996) The molecular basis of dehydration tolerance in plants. Annual Review of Plant Physiology and Plant Molecular Biology 47, 377-403.

International Seed Testing Association (ISTA) (2016) International Rules for Seed Testing. Zurich: ISTA.
Karner, U., Peterbauer, T., Raboy, V., Jones, D.A., Hedley, C.L. and Richter, A. (2004) myo-Inositol and sucrose concentrations affect the accumulation of raffinose family oligosaccharides in seeds. Journal of Experimental Botany 55, 1981-1987.

Kermode, A.R. (1997) Approaches to elucidate the basis of desiccation-tolerance in seeds. Seed Science Research 7, 75-95.

Kollipara, K.P., Saab, I.N., Wych, R.D., Lauer, M.J. and Singletary, G.W. (2002) Expression profiling of reciprocal maize hybrids divergent for cold germination and desiccation tolerance. Plant Physiology 129, 974-992.

Koster, K.L. and Leopold, A.C. (1988) Sugars and desiccation tolerance in seeds. Plant Physiology 88, 829-832.

Krochko, J.E. and Bewley, J.D. (1990) Identification and characterization of the seed storage proteins of alfalfa (Medicago sativa L.). Journal of Experimental Botany 41, 505-514.

Laemmli, U.K. (1970) Cleavage of structural proteins during the assembly of the head of bacteriophage T4. Nature 227, 680-685.

Lahuta, L.B., Górecki, R.J., Zalewski, K. and Hedley, C.L. (2007) Sorbitol accumulation during natural and accelerated ageing of pea (Pisum sativum L.) seeds. Acta Physiologia Plantarum 29, 527-534.

Letchworth, M. and Lambert, R. (1998) Pollen parent effects on oil, protein, and starch concentration in maize kernels. Crop Science 38, 363-367.

Li, X., Zhuo, J., Jing, Y., Liu, X. and Wang, X. (2011) Expression of a GALACTINOL SYNTHASE gene is positively associated with desiccation tolerance of Brassica napus seeds during development. Journal of Plant Physiology 168, 1761-1770.

Lisec, J., Romisch-Margl, L., Nikoloski, Z., Piepho, H.P., Giavalisco, P., Selbig, J., Gierl, A. and Willmitzer, L. (2011) Corn hybrids display lower metabolite variability and complex metabolite inheritance patterns. Plant Journal 68, 326-336.

Lowe, L.B. and Ries, S.K. (1973) Endosperm protein of wheat seed as a determinant of seedling growth. Plant Physiology 51, 57-60.

Marcos-Filho, J. (2015a) Seed Physiology of Cultivated Plants [in Portuguese], 2nd edition. Londrina, PR, Brazil: ABRATES.

Marcos-Filho, J. (2015b) Seed vigor testing: an overview of the past, present and future perspective. Sciencia Agricola 72, 363-374.

McDonough, C.M., Floyd, C.D., Waniska, R.D. and Rooney, L.W. (2004) Effect of accelerated aging on maize, sorghum, and sorghum meal. Journal of Cereal Science 39, 351-361.

Moterle, L.M., Braccini, A.L., Scapim, C.A., Pinto, R.J., Gonçalves, L.S., Amaral-Júnior, A.T. and Silva, T.R. (2011) Combining ability of tropical maize lines for seed quality and agronomic traits. Genetics and Molecular Research 10, 2268-2278.

Murthy, U.M.N., Kumar, P.P. and Sun, W.Q. (2003) Mechanisms of seed ageing under different storage conditions for Vigna radiata (L.) Wilczek: lipid peroxidation, sugar hydrolysis, Maillard reactions and their relationship to glass state transition. Journal of Experimental Botany 54, 1057-1067.

Murthy, U.M.N. and Sun, W.Q. (2000) Protein modification by Amadori and Maillard reactions during seed storage: 
roles of sugar hydrolysis and lipid peroxidation. Journal of Experimental Botany 51, 1221-1228.

Nakagawa, J. (1999) Vigor tests based on seedlings assessment [in Portuguese]. In Krzyzanowski, F.C. et al. (eds), Seed Vigour: Concepts and Tests, pp. 2.1-2.21. Londrina, Brazil: ABRATES.

Navratil, R.J. and Burris, J.S. (1984) The effect of drying temperature on corn seed quality. Canadian Journal of Plant Sciences 64, 487-496.

Nishizawa-Yokoi, A., Yabuta, Y. and Shigeoka, S. (2008) The contribution of carbohydrates including raffinose family oligosaccharides and sugar alcohols to protection of plant cells from oxidative damage. Plant Signaling and Behaviour 3, 1016-1018.

Nosarzewski, M., Downie, A.B., Wu, B. and Archbold, D.D. (2012) The role of SORBITOL DEHYDROGENASE in Arabidopsis thaliana. Functional Plant Biology 39, 462-470.

Ordas, B., Malvar, R.A., Ordas, A. and Revilla, P. (2008) Reciprocal differences in sugary $\times$ sugary enhancer sweet corn hybrids. Journal of the American Society of Horticultural Science 133, 777-782.

Osborne, T.B. (1924) The Vegetable Proteins. New York: Longmans, Green and Co.

Pollmer, W.G., Klein, D. and Dhillon, B.S. (1979) Differences in reciprocal crosses of maize inbred lines diverse for protein content. Euphytica 28, 325-328.

Rao, A.P. and Fleming, A.A. (1978) Cytoplasmic-genotypic effects in the GT 112 maize inbred with four cytoplasms. Crop Science 18, 935-937.

Reyes, F.C., Chung, T., Holding, D., Jung, R., Vierstra, R. and Otegui, M.S. (2011) Delivery of prolamins to the protein storage vacuole in maize aleurone cells. Plant Cell 23, 769-784.

Rosseto, C.A.V., Lima, T.M. and Guimaraes, E.C. (2004) Accelerated aging and controlled deterioration of peanut seeds. Pesquisa Agropecuaria Brasileira 39, 795-801.

Roveri-José, S.C.B., Von-Pinho, E.V.R. and Dias, M.A.G.S. (2006) Sugars and tolerance to high drying temperature in corn seeds [in Portuguese, with English abstract]. Revista Brasileira de Sementes 28, 60-68.

Roveri-José, S.C.B., Von-Pinho, E.V.R., Von-Pinho, R.G., Ramalho, M.A.P. and Silva-Filho, J.L. (2004) Genetic control of corn seeds tolerance to high drying temperature [in Portuguese, with English abstract]. Revista Brasileira de Milho e Sorgo 3, 414-428.

Schmidt, M.A., Barbazuk, W.B., Sandford, M., May, G., Song, Z., Zhou, W., Nikolau, B.J. and Herman, E.M. (2011) Silencing of soybean seed storage proteins results in a rebalanced protein composition preserving seed protein content without major collateral changes in the metabolome and transcriptome. Plant Physiology 156, 330-345.

Singh, S., Ambastha, V., Levine, A., Sopory, S.K., Yadava, P.K., Tripathy, B.C. and Tiwari, B.S. (2015) Anhydrobiosis and programmed cell death in plants: commonalities and differences. Current Plant Biology 2, 12-20.
Song, R. and Messing, J. (2003) Gene expression of a gene family in maize based on non-collinear haplotypes. Proceedings of the National Academy of Sciences USA 100, 9055-9060.

Strelec, I., Ugarčić-Hardi, Ž., Balkić, J. and Šimunić, N. (2007) Enzymatic activity in wheat seeds of different protein content. Agriculturae Conspectus Scientificus 72, 239-243.

Stupar, R.M. and Springer, N.M. (2006) Cis-transcriptional variation in maize inbred lines B73 and Mo17 leads to additive expression patterns in the $F_{1}$ hybrid. Genetics 173, 2199-2210.

Swanson-Wagner, R.A., DeCook, R., Jia, Y., Bancroft, T., Ji, T., Zhao, X., Nettleton, D. and Schnable, P.S. (2009) Paternal dominance of trans-eQTL influences gene expression patterns in maize hybrids. Science 326, 1118-1120.

Taji, T., Ohsumi, C., Iuchi, S., Seki, M., Kasuga, M., Kobayashi, M., Yamaguchi-Shinozaki, K. and Shinozaki, K. (2002) Important roles of drought- and cold-inducible genes for galactinol synthase in stress tolerance in Arabidopsis thaliana. Plant Journal 29, 417-426.

Tomić, J., Torbica, A., Popović, L., Strelec, I., Vaštag, Ž., Pojić, M. and Rakita, S. (2015) Albumins characterization in relation to rheological properties and enzymatic activity of wheat flour dough. Journal of Agricultural Science and Technology 17, 805-816.

United States Department of Agriculture (USDA) (2015) Crop production 2014 summary (January 2015). USDA, National Agricultural Statistics Service, USA. https://www.census.gov/history/pdf/cropan15.pdf (accessed 02 Apr. 2017).

Vandecasteele, C., Teulat-Merah, B., Morère-Le Paven, M. C., Leprince, O., Vu, B.L., Viau, L., Ledroit, L., Pelletier, S., Payet, N., Satour, P., Lebras, C., Gallardo, K., Huquet, T., Limami, A.M., Prosperi, J.M. and Buitink, J. (2011) Quantitative trait loci analysis reveals a correlation between the ratio of sucrose/raffinose family oligosaccharides and seed vigour in Medicago truncatula. Plant, Cell and Environment 34, 1473-1487.

Wang, Y. and Frei, M. (2011) Stressed food - the impact of abiotic environmental stresses on crop quality. Agriculture, Ecosystems and Environment 141, 271-286.

Wang, X., and Larkins, B.A. (2001) Genetic analysis of amino acid accumulation in opaque- 2 maize endosperm. Plant Physiology 125, 1766-1777.

Wettlaufer, S.H. and Leopold, A.C. (1991) Relevance of Amadori and Maillard products to seed deterioration. Plant Physiology 97, 165-169.

Wu, Y. and Messing, J. (2014) Proteome balancing of the maize seed for higher nutritional value. Frontiers in Plant Science 5, 240. doi: 10.3389/fpls.2014.00240

Zhao, T.Y., Thacker, R., Corum, J.W., Snyder, J.C., Meeley, R. B., Obendorf, R.L. and Downie, B. (2004) Expression of the maize GALACTINOL SYNTHASE gene family: (I) expression of two different genes during seed development and germination. Physiologia Plantarum 121, 634-646. 